\title{
Do dissemination and risks increase the willingness to disclose assets?
}

\author{
Isti Rahayu \\ Accounting Department, Universitas Islam Indonesia, Yogyakarta, Indonesia \\ isti_rahayu@uii.ac.id \\ Shofi Yasmina Ruhin \\ Accounting Department, Universitas Islam Indonesia, Yogyakarta, Indonesia
}

Follow this and additional works at: https://journal.uii.ac.id/jca

Copyright (C2019 Journal of Contemporary Accounting and Authors.

To cite this article: Isti Rahayu \& Shofi Yasmina Ruhin. (2019). Do dissemination and risks increase the willingness to disclose assets? Journal of Contemporary Accounting, 1(3), 145-152. doi:10.20885/jca.vol1.iss3.art2 


\title{
Do dissemination and risks increase the willingness to disclose assets?
}

\author{
Isti Rahayu ${ }^{1}$, Shofi Yasmina Ruhin ${ }^{2}$ \\ 1,2Accounting Department, Universitas Islam Indonesia, Yogyakarta, Indonesia
}

JEL Classification:

H21, H26

Keywords:

PAS-Final, dissemination, risks.

\section{Corresponding Author:}

isti_rahayu@uii.ac.id

DOI:

10.20885/jca.vol1.iss3.art2

Copyright @2019

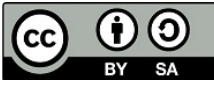

This is an open access under CC-BY-SA LICENSE

\begin{abstract}
This research aims to find out the influence of taxpayers' knowledge on the willingness to disclose assets strengthened by dissemination and risks of sanction impositions. The research sample is the taxpayers listed in the tax office. A total sample of 103 taxpayers was taken using convenience sampling method. Tests were carried out using moderated regression analysis. The research findings reveal that taxpayers' knowledge has a positive influence on the willingness to disclose assets, the risks of sanction impositions moderate the influence of taxpayers' knowledge on the willingness to disclose assets, while dissemination does not moderate the influence of taxpayers' knowledge on the willingness to disclose assets. Therefore, an increase in taxpayers' knowledge is needed, primarily on tax sanctions as it is evident to strengthen the influence of taxpayers' knowledge on the willingness to disclose assets.
\end{abstract}

\section{Introduction}

Tax revenues contribute the most to the Indonesian economy. The realization of tax revenues in the country is always rising each year, it can be seen from the realization of tax revenues in 2016 that amounted to Rp1,285 trillion, in $2017 \mathrm{Rp}$ 1,344 trillion, and in $2018 \mathrm{Rp} 1,519$ trillion (Badan Pusat Statistik, 2019). Tax revenues that continue to increase over the years are closely tied to the government's role to boost state revenue. One of the government's strategies fulfil tax target is by establishing tax amnesty program. After the tax amnesty program ended in March, 2017, the data from the Directorate General of Taxation showed that the taxpayers who participated in the program were only 2.7 percent, that is amounted to 972,000 taxpayers out of 36 million taxpayers. The details are as follows: (1) Individual taxpayers of SMEs amounting to 321,895 taxpayers, (2) Individual taxpayers of non-SMEs amounting to 413,613 taxpayers, (3) Corporation taxpayers of SMEs amounting to 111,238 taxpayers, (4) Corporation taxpayers of non SMEs amounting to 125,784 taxpayers. The data has informed that tax amnesty program in Indonesia is categorized to be less fruitful, even though the state revenue from the program reached Rp135 trillion. The revenue comprises a ransom of Rp114 trillion, payments of preliminary proof $\mathrm{Rp} 1.75$ trillion, and payments of arrears Rp 18.6 trillion (Siahaan, 2017).

After the tax amnesty program had ended, the government issued a new program commonly called PAS-Final (voluntary disclosure) (OnlinePajak, 2017). PAS-Final program (voluntary disclosure) aims to provide justice and opportunities to taxpayers who have not disclosed their assets. Although the program looks similar to the tax amnesty, the Directorate General of Taxation asserted the program is no tax amnesty volume two, as they have a few difference in examination.

An attitude towards behaviour is not influenced towards behaviour compliance on taxpayer in Indonesia (Putra \& Osman, 2019). Knowledge on taxation and tax sanction did not influence 
the compliance of individual taxpayers running business or doing freelance work, this showed that the low levels of knowledge on taxation and understanding on the procedures of tax payment and reporting owned by the taxpayers (Meidawati \& Azmi, 2019).

This research study aims to examine the influence of taxpayers' knowledge on the willingness to disclose assets, the role of dissemination in the influence of taxpayers' knowledge on the willingness to disclose assets, and the role of sanction risks in strengthening the effect of taxpayers' knowledge on the willingness to disclose assets.

\section{Literature Review}

\section{Attribution and Prospect Theories}

Attribution theory provides a framework to make sense of how an individual explains an event that happens to him/her (Martinko \& Mackey, 2019). The theory states that one's behaviour is determined by internal and external factors. When individuals observe one's behaviour, they attempt to determine whether it is caused by internal or external factors. The behaviour caused by internal factors is the one that is believed to be under the personal control of the individual, while the behaviour caused by external factors is the one that is influenced from outside, meaning that the individual will be forced to behave because of certain situations. Attribution theory can explain taxpayers' willingness affected by both internal and external factors. One of the external factors is dissemination by the Directorate General of Taxation.

Meanwhile, prospect theory explains an analysis of one's behaviour in making decisions (Kahneman \& Tversky, 1979). One would calculate profits/losses from the decisions made. Put it simply, risks tend to be rejected when under profiTable conditions, otherwise they tend to be accepted when under loss conditions.

\section{The Willingness to Disclose Assets}

PAS-Final (voluntary disclosure) is the procedure that provides taxpayers the opportunities to submit assets that have not been disclosed in the Asset Declaration Letter (participants of Tax Amnesty) or have not been reported in the Tax Return after the end of the Amnesty Tax period with certain conditions. All provisions governing the disclosure of voluntary assets subject to income tax is final and are regulated in the Minister of Finance Regulation number 165/PMK.03/2017 concerning the Second Amendment to the Minister of Finance Regulation Number 118/PMK.03/2016 concerning the Implementation of Act Number 11 , 2016 on Tax Amnesty (Pemerintah Republik Indonesia, 2017). The government provides taxpayers the opportunities to report their assets before the Directorate General of Taxation finds the unreported assets. But, when the Directorate General of Taxation finds them, the opportunity for voluntary disclosure has ended, the taxpayer will be sanctioned subject to article18 of the Tax Amnesty Act.

\section{Taxpayers' knowledge}

The knowledge of having an opportunity to disclose assets can be gained by interactions with the community, one of which is the dissemination by tax officials with respect to the related rules or information from news. Taxpayers with well-informed understanding of the tax rules that apply will be likely to have higher tax compliance. If only the disobedience occurs, it might be unintentional, for instance the taxpayer has not understood the rules that apply. There are a few studies that have examined this topic. Wardani and Rumiyatun (2017) suggested that taxpayers' knowledge had a positive influence on tax compliance. Suari and Rasmini (2018) found that the understanding of tax rules had a positive influence on the willingness to participate in Tax Amnesty. Purnamasari et al. (2016) suggested the understanding of tax rules had a positive influence on tax compliance. Anggara and Sulistiyanti (2016) also showed that the understanding had a positive 
significant influence on tax compliance. Based on the explanation, a hypothesis is proposed as follows:

$\mathbf{H}_{1}$ : Taxpayers' knowledge has a positive influence on the willingness to disclose assets.

\section{Taxation Dissemination}

Taxation dissemination is an effort by the Directorate General of Taxation to provide knowledge, skills, values, and norms regarding things relating to taxation regulations and acts. Information delivery by the government will highly affect taxpayers' awareness to pay taxes. As it is wellacknowledged that one's behaviour is affected by both internal and external factor, one of the external ones that can affect taxpayers' behaviour is dissemination by the Directorate General of Taxation. Nustini and Afianto (2017) suggested that dissemination had a significant effect on tax compliance. Anggara and Sulistiyanti (2016) also found that taxation dissemination had a positive significant effect on tax compliance. Tambun (2016) revealed that taxation dissemination could moderate knowledge, professional commitment, fiscus services and sanctions on tax compliance. Megawangi and Setiawan (2017) showed that taxation dissemination could moderate the effect of taxpayers' awareness on tax compliance of corporation taxpayers. Based on these research findings, a hypothesis is proposed as follows:

$\mathbf{H}_{2}$ : Taxation dissemination moderates the influence of taxpayers' knowledge on the willingness to disclose assets.

\section{Risks of Sanction Impositions}

Prospect theory states that the decisions made in a risky condition, such as a state of uncertainty, may lead to a difficulty of predicting the consequences or results from the events (Kahneman \& Tversky, 1979). The decision making involves internal conflict on the trade-off value, which is a difficult choice when values are contradictory. According to prospect theory, when a taxpayer encounters a risk, the risk might affect the decision making by the taxpayer. This is corroborated by a few prior studies. Savitri and Nuraina (2017) suggested that tax sanctions had a positive influence on tax compliance. Suari and Rasmini, (2017) found that tax sanctions had a positive influence on the willingness to participate in Tax Amnesty. Nustini and Afianto (2017) revealed that sanctions moderated the relationships between taxation dissemination and motorcycleownership tax compliance. Thus, a hypothesis is proposed as follows:

$\mathbf{H}_{3}$ : Risks of sanction impositions moderate the influence of taxpayers' knowledge on the willingness to disclose assets.

\section{Research Model}

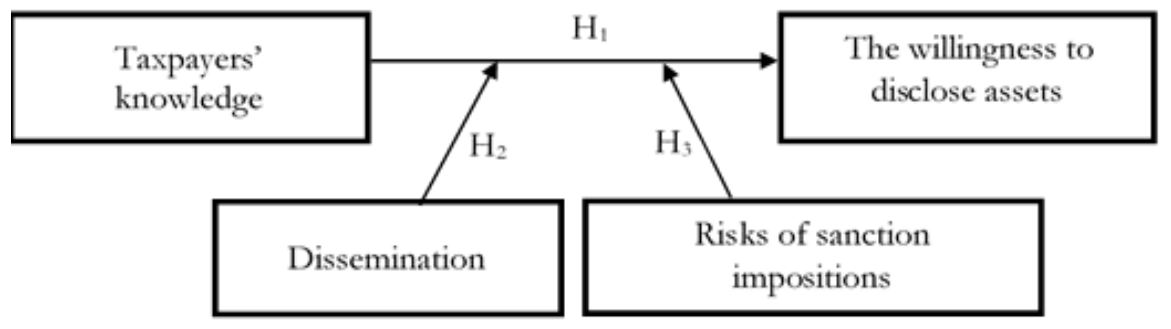

Figure 1: Research Framework

\section{Research Method}

\section{Population and Sample}

This research study uses primary data originated from individual taxpayers listed on a variety of Tax Offices (KPP). The data were gathered by distributing questionnaire to each respondent by: (a) 
meeting the taxpayers directly in person; (b) sending the questionnaires to the taxpayers via emails, Whatsapp, and Line. There were approximately 105 questionnaires distributed, the ones submitted back and could be processed were 103 questionnaires. The questionnaires are created by using a fournumber Likert scale: (1) Strongly Disagree, (2) Disagree, (3) Agree, (4) Strongly Agree.

\section{Research Variables}

\section{Dependent variable: the willingness to disclose assets}

The willingness to disclose assets is the internal drive of the taxpayer to report assets that have not been listed on the Asset Declaration Letter or Annual Income Tax Return through PAS-Final programme. This variable is measured by using a questionnaire of 7 questions: (1) I have the willingness to disclose assets If I know the procedures of PAS-Final, (2) I have the willingness to disclose assets as I don't want to be sanctioned (3) I have the willingness to disclose assets as I don't expect my business activities/job have tax problems, (4) I have the willingness to disclose assets as I don't want to be seen as a disobedient taxpayer, (5) I have the willingness to disclose assets even though I don't obtain complete information on PAS- final from the tax office, (6) I have the willingness to disclose assets even though I don't obtain the technical explanation on the procedures of the DGT's provisions, (7) I have the willingness to disclose assets if the tax officials encourage me to comply with the tax provisions.

\section{Independent variable: taxpayers' knowledge}

Taxpayers' knowledge is the things the taxpayer knows with respect to taxation, especially PASFinal. This variable is measured by using a questionnaire of 7 questions:(1) I know that the government's tax target is always rising each year, (2) I know the obligations to report income, assets, and liabilities on the Tax Return, (3) I know that I must fill out the Tax Return in a correct, clear, complete way, (4) I understand that the government has provided taxpayers the opportunity to disclose assets through PAS-Final, (5) I know the purpose of PAS-Final, (6) I know the administrative sanctions in the PAS-Final regulation, (7) I understand the risks that I might face if I don't follow the PAS-Final provisions.

\section{Moderating variables: tax dissemination}

Tax dissemination is an effort by the Directorate General of Taxation to provide knowledge, skills, values, and norms with respect to taxation regulations and acts. The moderating variable of dissemination is measured by using a questionnaire of 7questions: (1) I regularly follow the taxation dissemination conducted by the DGT, (2) Taxation dissemination really helps me understand the taxation provisions on PAS-Final, (3) Dissemination is provided by the officials through seminars, brochures, social media, and counselling, (4) Taxation dissemination implemented is effective and right on target, (5) I have read the taxation brochures on PAS-Final by DJP through mass media such as online or electronic media, (6) I have heard of taxation audio on PAS-Final by DGT through electronic media, (7) I understand the content delivered by tax officials through PAS-Final dissemination conducted directly via print/electronic media.

\section{Risks of Sanction Impositions}

Risk of sanction impositions is a state of uncertainty about the loss that will arise if the taxpayer is subject to sanctions. This moderating variable is measured by using a questionnaire of 7 questions: (1) Tax sanctions are necessary in order to encourage discipline in taxpayers fulfilling tax obligations, (2) The imposition of sanctions should be done firmly on all disobedient taxpayers, (3) The application of tax sanctions should be accordance with the applicable regulations, (4) I know what sanctions to be imposed, if taxation violation occurs, (5) I will potentially get imposed an 
administrative sanction on net assets that have not been reported or less reported, if only they are found by the tax officials, (6) I don't want to get imposed an administrative sanction on the unreported/less reported assets, (7) The amount of administrative sanction on the unreported/less reported assets costs me a lot.

\section{Regression Equation}

Based on the relationship between the variables of taxpayers' knowledge (X1), the willingness to disclose assets $(\mathrm{Y})$, dissemination (Z1), risks of sanction impositions (Z2), the following linear regression analysis model is used:

$\mathrm{Y}=\alpha+\beta_{1} \mathrm{X}_{1}$

$\mathrm{Y}=\alpha+\beta_{1} \mathrm{X}_{1}+\beta_{4}\left(\mathrm{X}_{1} * \mathrm{Z}_{1}\right)+\beta_{5}\left(\mathrm{X}_{1} * \mathrm{Z}_{2}\right)+\mathrm{e}$

\section{Results and Discussion}

\section{Description of Respondents}

This research study was done using a sample of 103 respondents with the following description.

Table 1. Description of Respondents

\begin{tabular}{lll}
\hline Information & Number & $\%$ \\
\hline Gender: & 40 & $39 \%$ \\
Female & 63 & $61 \%$ \\
Male & & \\
Education: & 1 & $1 \%$ \\
SMP & 22 & $21 \%$ \\
SMA & 71 & $69 \%$ \\
Bachelor Degree & 2 & $9 \%$ \\
Post Graduate & & \\
Profession: & 22 & $21 \%$ \\
Civil Servants & 29 & $28 \%$ \\
Private sector & 37 & $36 \%$ \\
Entrepreneurs & 15 & $15 \%$ \\
Others & & $45 \%$ \\
Participated in Tax Amnesty: & 46 & $55 \%$ \\
Yes & 57 & $8 \%$ \\
No & & $92 \%$ \\
Participated in PAS-Final: & 8 & \\
Yes & 95 & \\
No & & \\
\hline
\end{tabular}

Table 1 presents that the majority of the sample have bachelor degree for their educational background, with a variety of professions - in private sectors, entrepreneurs, and others. Of the entire respondents, 45\% participated in tax amnesty, while participated in PAS Final is 8 percent.

\section{Descriptive Statistics}

Table 2. Descriptive Statistics

\begin{tabular}{llllll}
\hline & $\mathrm{N}$ & Minimum & Maximum & Mean & Std. Deviation \\
\hline Knowledge & 103 & 1.71 & 4.00 & 3.2304 & 0.58916 \\
Dissemination & 103 & 1.00 & 3.86 & 2.8462 & 0.58909 \\
Risks & 103 & 1.86 & 4.00 & 3.3469 & 0.42694 \\
Willingness & 103 & 1.80 & 4.00 & 3.3495 & 0.46249 \\
\hline
\end{tabular}


Based on the descriptive statistics, the variable of dissemination has an average value of 2.846. Such value is the lowest value among the variables.

\section{Results of Validity, Reliability, and Regression Fitness Tests}

Results of validity test show that all indicators are valid with a Sig. value smaller than 0.05 . Based on the results of reliability test, the value of Cronbach's Alpha on the variable of taxpayers' knowledge is 0.892 , the variable of dissemination is 0.886 , the variable of risks of sanction impositions is 0.741 , and on the variable of the willingness to disclose assets is 0.808 . All the variables have a value of Cronbach's Alpha larger than 0.60 , that the question items are declared reliable.

Based on the results of normality test, obtained Asymp. Sig. (2-tailed) 0.200. Such value is larger than 0.05 , that the data are normally distributed. In addition, multicollinearity does not occur on all the variables. The data also reveal that each variable has a tolerance value of $0.467,0.399$, 0.528 which are larger than 0.10 . On the VIF value, each variable has a value of $2.140,2.508,1.892$ which are smaller than 10 . Meanwhile, in the heteroscedasticity test, all variables have a sig. value larger than 0.05 - the knowledge variable is 0.319 , the dissemination variable is 0.254 , and the risk variable is 0.609 . Thus, such regression model is free from heteroscedasticity.

\section{Results of Hypothesis Testing}

Results of hypothesis 1 testing - Knowledge has a positive influence on the willingness to disclose assets can be seen on Table 3 .

The variable of knowledge has a positive regression coefficient of 0.365 which indicates that if the taxpayers' knowledge gets increased, the willingness to disclose assets will be inclined to rise. From the hypothesis testing, the value of Sig. is 0.000 . Such value is smaller than 0.05 , and it means that $\mathrm{H} 1$ has been proven. Thus, taxpayers' knowledge has a positive influence on the willingness to disclose assets. The better the knowledge relating to PAS-Final, the stronger the willingness to disclose assets voluntarily. This research finding supports the finding by Suari \& Rasmini (2017), revealing that the understanding of taxation rules had a positive influence on the willingness to participate in tax amnesty, and the finding by Anggara \& Sulistiyanti (2016) proving that the understanding affected tax compliance.

Table 3: Results of Linear Regression of Equation (1) and Equation (2)

\begin{tabular}{|c|c|c|c|c|}
\hline \multirow[t]{2}{*}{ Equation 1} & \multicolumn{2}{|c|}{ Unstandardized Coefficients } & \multirow{2}{*}{$\begin{array}{l}\text { Standardized } \\
\text { Coefficients } \\
\text { Beta }\end{array}$} & \multirow[t]{2}{*}{ Sig. } \\
\hline & $\mathrm{B}$ & Std. Error & & \\
\hline (Constant) & 2.200 & 0.229 & & 0.000 \\
\hline Knowledge & 0.365 & 0.070 & 0.453 & 0.000 \\
\hline \multicolumn{5}{|c|}{ R Square $=0.206$} \\
\hline \multicolumn{5}{|l|}{ Equation 2} \\
\hline (Constant) & 2.960 & 0.252 & & 0.000 \\
\hline Knowledge & -0.629 & 0.172 & -0.801 & 0.000 \\
\hline$P \times S$ & -0.014 & 0.029 & -0.094 & 0.628 \\
\hline P_x_R & 0.233 & 0.036 & 1.438 & 0.000 \\
\hline R Square $=0.463$ & & & & \\
\hline
\end{tabular}

Table 3 also displays that the variable of dissemination has a Sig. value of 0.628 . This value is larger than 0.05 , and it means that $\mathrm{H} 2$ is not proven. Thus, dissemination does not moderate the influence of taxpayers' knowledge on the willingness to disclose assets. It indicates a likelihood of less dissemination by tax officials. Consequently, taxpayers have weak willingness to disclose assets 
because they have not been provided with complete and clear information. This research finding contrasts with a study by Megawangi and Setiawan (2017) revealing that taxation dissemination could moderate the influence of taxpayers' awareness on tax compliance of corporation taxpayers, but corroborates a study by Susanti and Khairan (2017) proving that the variable of dissemination did not moderate the relationship between tax sanctions and the willingness to pay taxes.

Testing the moderating variable of risk has yielded a value of Sig.is 0.000 . Such value is smaller than 0.05 , which means $\mathrm{H} 3$ has been proven, that risk of sanction impositions moderates the effect of taxpayers' knowledge on the willingness to disclose assets. This research finding is in line with a study by Nustini and Afianto (2017) showing that sanctions moderated the relationship between taxation dissemination and motorcycle-ownership tax compliance. In addition, it is also in line with a study by Suari and Rasmini (2018) that suggested tax sanctions had a positive influence on the willingness to participate in Tax Amnesty. This current research has successfully examined prospect theory stating that one would calculate profits or losses from the decisions made.

\section{Test of $F^{2}$ (Effect Size)}

To see the extent to which the influence of risk on moderating variable, effect size test is conducted divided into 3 categories - (1) small effect if $\mathrm{F}^{2}>0.02$, (2) medium effect if $\mathrm{F}^{2}>0.15$; (3) large effect if $\mathrm{F}^{2}>0.35$. The test has yielded 0.478 which is larger than 0.35 . It indicates the effect size of the risk's variable moderates the influence of taxpayers' knowledge on the willingness to disclose assets in a strong extent. This research study has successfully proven prospect theory stating that one would calculate profits or losses from the decisions made.

\section{Conclusions}

It can be concluded that taxpayers' knowledge has a positive influence on the willingness to disclose assets. Dissemination does not moderate the influence of taxpayers' knowledge on the willingness to disclose assets. Meanwhile, risks of sanction impositions moderate the influence of knowledge on the willingness in a strong extent, supported by the effect size test. This research study has proven prospect theory that one's decision making is affected by risks being encountered.

This current research is limited to tax compliance, primarily the willingness to disclose assets with a sample of 103 taxpayers. It is recommended that further studies extend research areas and add more the amount of sample, so that the research results can be more generalized. The DGT's research results also reveal that taxpayers' knowledge should be improved, primarily on tax sanctions as it has been proven to strengthen taxpayers' knowledge on the willingness to disclose assets.

\section{References}

Anggara, A. B., \& Sulistiyanti, U. (2016). Kepatuhan pajak usaha mikro, kecil dan menengah di Surakarta. In Simposium Nasional Akuntansi XIX (pp. 17-22). Jember: Ikatan Akuntan Indonesia Kompartemen Akuntan Pendidik (IAI KAPd).

Badan Pusat Statistik. (2019). Realisasi Pendapatan Negara. Retrieved from https://www.bps.go.id/staticTable/2009/02/24/1286/realisasi-pendapatan-negara-milyarrupiah-2007-2018.html. Accessed on 30 June 2019.

Kahneman, D., \& Tversky, A. (1979). Prospect theory: An analysis of decision under risk. Econometrica, 47(2), 263-292.

Martinko, M. J., \& Mackey, J. D. (2019). Attribution theory: An introduction to the special issue. Journal of Organizational Behavior, 40(5), 523-527. https://doi.org/10.1002/job.2397

Megawangi, C. A. M., \& Setiawan, P. E. (2017). Sosialisasi perpajakan memoderasi pengaruh 
kesadaran wajib pajak dan kualitas pelayanan pada kepatuhan wajib pajak badan. E Jurnal Akuntansi, 19(3), 2348-2377.

Meidawati, N., \& Azmi, M. N. (2019). Factors influencing the compliance of taxpayers. Journal of Contemporary Accounting, 1(1), 26-37. https://doi.org/10.20885/jca.vol1.iss1.art3

Nustini, Y., \& Afianto, F. (2017). Determinan kepatuhan pembayaran pajak kendaraan bermotor: Sanksi pajak sebagai variabel moderasi. In Simposium Nasional Akuntansi XX (pp. 26-27). Jember: Ikatan Akuntan Indonesia Kompartemen Akuntan Pendidik (IAI KAPd).

OnlinePajak. (2017). Pas Final: Pengungkapan Aset Sukarela dengan Tarif Final Pasca Tax Amnesty. Retrieved from https://www.online-pajak.com/tentang-pph21/pas-finalpengungkapan-aset-sukarela-tarif-final-pasca-tax-amnesty. Accessed on 29 June 2019.

Pemerintah Republik Indonesia. (2017). PMK Nomor 165-PMK 03-2017 tentang PAS-Final.

Purnamasari, A., Pratiwi, U., \& Sukirman, S. (2016). Pengaruh pemahaman, sanksi perpajakan, tingkat kepercayaan pada pemerintah dan hukum, serta nasionalisme terhadap kepatuhan wajib pajak dalam membayar Pbb-P2 (studi pada wajib pajak PBB-P2 di kota Banjar, Jawa Barat). Jurnal Akuntansi dan Auditing, 14(1), 22-39. https://doi.org/10.14710/jaa.14.1.22-39

Putra, A. F., \& Osman, A. H. (2019). Tax compliance of MSME's taxpayer: Implementation of theory of planned behavior. Journal of Contemporary Accounting, 1(1), 1-10. https://doi.org/10.20885/jca.vol1.iss1.art1

Savitri, F., \& Nuraina, E. (2017). Pengaruh sanksi perpajakan terhadap kepatuhan wajib pajak orang pribadi di Kantor Pelayanan Pajak Pratama Madiun. Equilibrium, 5(1), 45-55. http:// doi.org/10.25273/equilibrium.v5i1.1005

Siahaan, M. P. (2017). Tax Amnesty di Indonesia. Jakarta: Raja Grafindo Persada.

Suari, N. L. E. ., \& Rasmini, N. (2018). Pemahaman peraturan, efektivitas sistem, kewajiban moral, kualitas pelayanan, sanksi perpajakan pada kemauan ikut tax amnesty. E-Jurnal Akuntansi Universitas Udayana, 22(1), 108-137.

Tambun, S. (2016). Anteseden kepatuhan wajib pajak orang pribadi dan moderasi sosialisasi perpajakan. Media Akuntansi Perpajakan, 1(1), 26-40.

Wardani, D. K., \& Rumiyatun. (2017). Pengaruh pengetahuan wajib pajak, kesadaran wajib pajak, sanksi pajak kendaraan bermotor dan sistem samsat drive thru terhadap kepatuhan wajib pajak bermotor. Jurnal Akuntansi, 5(1), 15-24. 